
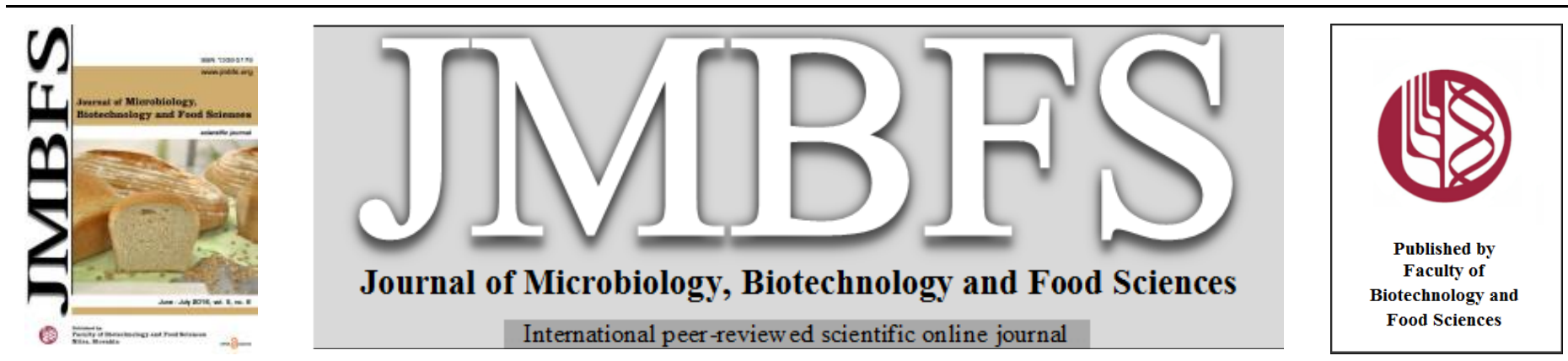

\title{
RAPID AND EFFICIENT METHOD FOR ENVIRONMENTAL DNA EXTRACTION AND PURIFICATION FROM SOIL
}

\author{
J. Hamedi ${ }^{1,2}$, M. Danaiefar ${ }^{1,2}$ and H. Moghimi ${ }^{1,2}$
}

Address(es):

${ }^{1}$ Department of Microbial Biotechnology, School of Biology and Center of Excellence in Phylogeny of Living Organisms, College of Science, University of Tehran, Tehran, Iran.

${ }^{2}$ Microbial Technology and Products Research Center, University of Tehran, Tehran, Iran.

*Corresponding author: jhamedi@ut.ac.ir

doi: 10.15414/jmbfs.2016.5.6.530-533

\section{ARTICLE INFO}

Received 19. 5. 2015

Revised 10.1.2016

Accepted 17. 1.2016

Published 1. 6. 2016

Regular article

open $\partial_{\text {ACCESS }}$

\begin{abstract}
Large proportion of microbial population in the world is unculturable. Extraction of total DNA from soil is usually a crucial step considering to the difficulties of study the uncultivable microorganisms. Humic acid is considered as the main inhibitory agent in the environmental DNA studies. Here, we introduced a rapid and efficient method for DNA extraction and purification from soil. Yield of DNA extraction by the presented method was $130 \mathrm{ng} / \mu 1$. Three conventional methods of DNA extraction including liquid nitrogen incursion, bead beating and sonication were performed as control methods. Yield of DNA extraction by these methods were 110, 90 and $50 \mathrm{ng} / \mu \mathrm{l}$, respectively. A rapid and efficient one step DNA purification method was introduced instead of hazardous conventional phenol-chloroform methods. Humic acid removal percentage by the introduced method was $95.8 \%$ that is comparable with $97 \%$ gained by the conventional gel extraction method and yield of DNA after purification was $84 \%$ and $73 \%$, respectively. This study could be useful in molecular ecology and metagenomics study as a fast and reliable method.
\end{abstract}

Keywords: DNA extraction, DNA purification, Environmental DNA, Metagenomics, Soil

\section{INTRODUCTION}

It is estimated that only less than $1 \%$ of bacteria in the world are culturable (Bürgmann et al. 2001). This limitation has let to problem that researchers lack a universal and perfect insight into microbial communities, their ecological importance and their potential role in biotechnology by standard microbia culture-based methods (Liles et al. 2008). Molecular based methods provide a useful and reliable approach to the unculturable microbial world studies (Lakay et al. 2006). One of the fundamental steps toward the study of uncultured microbial communities is the isolation of nucleic acids from the environmental samples in order to discover novel functional genes or to study the diversity and ecological aspects of selected environment (Young et al. 1993). Diverse methods have been developed and investigated to increase the yield of DNA extraction and purification (Robe et al. 2003). Type of the soil and biogeography of sampling environment greatly affect the diversity of microbial community and none of the extraction methods can be universally applied for all forms of soils (Liles et al. 2008). Various modalities including mechanical, physical and chemical enzymatic methods were used by Martin-Laurent et al. (2001) Mechanical methods such as incursion in liquid nitrogen (Zhou et al. 1996), sonication (Yeats et al. 1998), bead beating (Miller et al. 1999; Bürgmann et al. 2001), freeze-thawing cycles (Degrange and Bardin 1995) as physical methods and application of lysozyme (Stach et al. 2001) and hot-SDS approaches (Trevors et al. 1992) as chemical methods for cell lysis, are examples of DNA extraction tools. These approaches usually make the DNA sheared and fragmented so that it can make problems in proceeding (down-stream) steps such as construction of metagenomic library or performing PCR (Frostegard et al. 1999).

Humic acid compounds are difficult to remove and are usually co-extracted with nucleic acids. As a result, DNA purification and humic acid removal are the mos important steps in DNA isolation from soil (Young et al. 1993). Various methods are developed for purification of DNA and humic acid removal (Lakay $\boldsymbol{e t}$ al. 2006). Some of these methods are employed simultaneous with DNA extraction. Cetyltrimethylammonium Bromide (CTAB) (Zhou et al. 1996), Polyvinyl polypyrrolidone (PVPP) (Froestegard et al. 1999) and Guanidinium isothiocyanate (GITC) (Chen et al. 2010) compounds as well as high salt extraction conditions are used for DNA extraction and purification simultaneously. Agarose gel electrophoresis (More et al. 1994), Gel filtration resins including Sephadex G200 (Kuske et al. 1998) and commercial products such as DNA binding columns (Miller et al. 1999) are used for DNA purification after the extraction.

The objective of this study is to introduce the efficient high quality DNA isolation method from the soil, with less amount of DNA shearing and humic acid. Also, efficiency of extracted and purified DNA was examined by transformation efficiency of restrict digested extracted DNA as well as performance of $16 \mathrm{~S}$ rRNA and 18S rRNA PCR.

\section{MATERIAL AND METHODS}

\section{Soil sampling}

Three soil samples 1 (clay), 2 (sandy) and 3 (loamy) were collected from Zarrinabad, Mazandaran, Iran (“36²9'64.58 N”, “53²0’96.29 E”), Boroujerd, Khorramabad, Iran (“3343'53.23 N”, “48 15'96.19 E”) and Geophysics institute park, University of Tehran, Tehran, Iran (" $35^{\circ} 73$ '90.05 N", " $51^{\circ} 38$ '71.40 E") respectively. Superior layer $(3 \mathrm{~cm})$ was removed and the sampling performed from $3-15 \mathrm{~cm}$ in depth from the surface. The samples were transferred to laboratory and stored in $4^{\circ} \mathrm{C}$

\section{Environmental DNA extraction}

For all three samples, one gram of the soil was sieved with a $1 \mathrm{~mm}$ mesh and roots of the plants were removed as many as possible. Then, the soil pounded with mortar and pestle. Three conventional DNA extraction methods were used as control methods, including: Method A) liquid nitrogen incursion was performed. $5 \mathrm{ml}$ of DNA extraction buffer $(100 \mathrm{mM}$ Tris- $\mathrm{HCl} \mathrm{pH} 8.0,100 \mathrm{mM}$ sodium EDTA $\mathrm{pH} 8.0,100 \mathrm{mM}$ sodium phosphate $\mathrm{pH} 8.0,1.5 \mathrm{M} \mathrm{NaCl}, 1 \%$ CTAB) was added to the soil and lysis of microbial cells was followed by an enzymatic step in which $100 \mu \mathrm{l}$ of lysozyme solution $(25 \%)$ was added to the mixture and incubated for 1 hour in $37{ }^{\circ} \mathrm{C}$ (Zhou et al. 1996). Method B). After the addition of $5 \mathrm{ml}$ of $0.12 \mathrm{M}$ sodium phosphate buffer, one gram of glass beads $(0.1 \mathrm{~mm})$ was added to the soil and bead beating was done for 4 minutes in 5000 rpm. Lysozyme was used as described above in method A (Ogram et al. 1987). Method C) $5 \mathrm{ml}$ of extraction buffer $(100 \mathrm{ml}$ of $100 \mathrm{mM}$ Tris- $\mathrm{HCl} \mathrm{pH} 8.0$ $100 \mathrm{mM}$ sodium EDTA $\mathrm{pH} 8.0,1.5 \mathrm{M} \mathrm{NaCl}$ ) added to the soil and the mixture sonicated for 20 minutes in the frequency of $37 \mathrm{~Hz}$. Followed by 3 cycles of freeze-thaw in -70 and $65{ }^{\circ} \mathrm{C}$ temperature (Yeats et al. 1998). The introduced 
method (D) is: first, $5 \mathrm{ml}$ of Z-buffer (Allen et al. 2008) (100 mM Tris- $\mathrm{HCl}, 100$ mM Na $2 \mathrm{HPO}_{4}, \mathrm{NaH}_{2} \mathrm{PHO}_{4}$ 1:1 solution, 100 mM EDTA, $1.5 \mathrm{M} \mathrm{NaCl} \mathrm{pH} \mathrm{8.0)}$ was added to the pounded soil and the mixture carefully ground in liquid nitrogen, in the manner that layers of frozen buffer containing soil were picked up and incurred with pestle. After that, 1 gram of glass beads $(0.1 \mathrm{~mm})$ was added and the resulting mixture was vortexed for 10 minutes. Homogenized sample then, exposed to the lysozyme with previously described condition. Three cycles of freeze-thaw were done in temperatures mentioned before. In all of the four mentioned DNA extraction methods, the extraction proceeds with the treatment of $1.3 \mathrm{ml}$ of $20 \% \mathrm{SDS}$ in $65^{\circ} \mathrm{C}$ for $2 \mathrm{hrs}$. But for the method D, because of the previous applied lysis steps, the time of incubation reduced to $1 \mathrm{hr}$. Then, the samples were centrifuged for 12 minutes in $13000 \mathrm{rpm}$ and supernatant was transferred to $50 \mathrm{ml}$ centrifuge tube. Comparison of the methods used was shown in table 1 .

Table 1 Composition of various DNA extraction buffers and different lysis treatments for DNA extraction from soil, (+) addition, (-) nonaddition.

\begin{tabular}{|c|c|c|c|c|c|c|c|c|c|c|}
\hline \multirow[b]{2}{*}{ Method } & \multicolumn{3}{|c|}{ DNA extraction buffer } & \multicolumn{6}{|c|}{ Lysis treatments } & \multirow[b]{2}{*}{ Reference } \\
\hline & $\begin{array}{l}\text { Sodium- } \\
\text { phosphate }\end{array}$ & $\begin{array}{l}\text { Tris- } \\
\mathrm{HCl}\end{array}$ & $\mathrm{NaCl}$ & $\begin{array}{l}\text { Grinding in } \\
\text { liquid } \\
\text { nitrogen }\end{array}$ & $\begin{array}{l}\text { Glass } \\
\text { beads }\end{array}$ & Lysozyme & Sonication & $\begin{array}{l}\text { Freeze- } \\
\text { thawing }\end{array}$ & $\begin{array}{c}\text { SDS- } \\
\text { incubation } \\
\text { time (h) }\end{array}$ & \\
\hline A & + & + & + & + & - & + & - & - & 2 & $\begin{array}{l}\text { Zhou et } \\
\text { al. } 1996\end{array}$ \\
\hline B & + & - & - & - & + & + & - & - & 2 & $\begin{array}{c}\text { Ogram et } \\
\text { al. } 1987\end{array}$ \\
\hline C & - & + & + & - & - & - & + & + & 2 & $\begin{array}{l}\text { Yeast } \boldsymbol{e t} \\
\text { al. } 1998\end{array}$ \\
\hline D & + & + & + & + & - & + & - & + & 1 & $\begin{array}{c}\text { Current } \\
\text { study }\end{array}$ \\
\hline
\end{tabular}

\section{DNA Purification}

The cell lysate obtained was extracted and purified using two methods: 1- Conventional gel extraction method for DNA extraction and purification Phenol-chloroform extraction was done according to the standard protocol (Sambrook and Russell 2001). Precipitated DNA was then dissolved in $500 \mu \mathrm{l}$ of TE buffer (10 mM Tris, $10 \mathrm{mM}$ EDTA, pH 8.0) and stored in $-20{ }^{\circ} \mathrm{C}$. DNA was purified by running on agarose gel. $50 \mu 1$ of DNA was loaded into agarose gel and electrophoresis was done in $60 \mathrm{~V}$ for $2 \mathrm{hr}$. The DNA was then recovered from the gel by DNA Gel Extraction Kit (Qiagen, USA). Purity of DNA was measured by the spectrophotometer with the ratio of A260/280. Quality of DNA was further evaluated by ligation transformation efficiency and PCR reaction. 2- One step DNA extraction and purification from soil sample

An innovative rapid method for DNA purification was tested. The resulting supernatant from lysis step in method $\mathrm{D}$ was mixed with the 2 volumes of $\mathrm{NaI}$ solution including ( $90.8 \mathrm{~g} \mathrm{NaI}, 1.5 \mathrm{~g} \mathrm{Na}_{2} \mathrm{SO}_{3}, 6 \mathrm{M}$ Guanidine thiocyanate, 140 mM MES (2-[N-Morpholino] ethanesulfonic acid) $0.006 \%$ Phenol Red, $100 \mathrm{ml}$ $\mathrm{H}_{2} \mathrm{O}$ ) and an equal volume of prepared glass bead using of silica 325 mesh powder (Sigma USA, according to the company manual). The mixture was incubated for 5 minutes at room temperature. Besides, quick spin was done to pellet the glass particles. The pellet washed with $500 \mu$ l washing buffer $(10 \mathrm{mM}$ Tris- $\mathrm{HCl} \mathrm{pH} \mathrm{7.5,} \mathrm{80 \%} \mathrm{ethanol)} \mathrm{and} \mathrm{spined} \mathrm{three} \mathrm{times.} \mathrm{After} \mathrm{that,} \mathrm{the} \mathrm{pellet} \mathrm{dried}$ in $55^{\circ} \mathrm{C}$ and eluted by $50 \mu 1$ of elution buffer $(10 \mathrm{mM}$ Tris-HCl, $\mathrm{pH} 8.5)$.

\section{DNA quantity and quality measurement}

Total DNA extraction using control methods and introduced method in this study was examined by visualization with ethidium bromide and the purity of DNA was measured by the spectrophotometer device with A260/280 ratio (Jenway 6850 , England)

\section{Humic acid measurement}

Humic acid content in the mixture was calculated by measuring the absorbance at $465 \mathrm{~nm}$ (Wang and Takeshi 2011). Humic acid (Sigma) was used as standard. Polymerase chain reaction

Polymerase chain reaction (PCR) was performed on DNA product extracted by four methods using bacterial 16S rRNA universal primers 9F: (Forward: AAG AGT TTG ATC ATG GCT CAG) and 1541R: (Reverse: AGG AGG TGA TCC AAC CGC A) (Zhang et al. 2003), and also fungal 18S rRNA gene universal primers nu-SSU-0817: (Forward: TTA GCA TGG AAT AAT RRA ATA GGA) and nu-SSU-1536: (Reverse: ATT GCA ATG CYC TAT CCC CA) (PrevosteBoure et al. 2011). PCR reaction was performed with PCR Master Mix (Amplicon, Korea) using Thermocycler device (SensoQuest, Germany)

\section{Bacterial strains and vectors}

Escherichia coli strain XL1 blue (Novagen, USA) was selected as a host for competent cell preparation and transformation. Plasmid pUC19 (Novagen, USA) was used as a vector for ligation and transformation.

\section{Ligation, transformation and colony PCR}

The samples were successfully digested with restriction enzyme BamH1 (Fermentas, Germany) and ligated into pUC19 BamH1 digested vector. Ligation reaction was performed using $\mathrm{T}_{4}$ DNA ligase (Fermentas, Germany) with $5 \mu \mathrm{l}$ of
DNA, cloning was done using heat shock calcium chloride method. Positive white colony selection was performed on LB medium ( $1 \%$ Tryptone, $0.5 \%$ yeast extract, $0.5 \% \mathrm{NaCl}$ ) contain X-gal, Isopropyl- $\beta$-D-thiogalactoside (IPTG) and ampicillin (Sambrock and Russel 2001). In order to determine the size of inserted DNA fragments in bacteria, total E. coli DNA extracted by boiling method (Sambrook and Russell 2001) and PCR was done using pUC19 specific primers B1R (Reverse: CAC ATT TCC CCG AAA AGT GC) and B1F (Forward: ACG GTT CCT GGC CTT TTG C) (Setayesh et al. 2008).

\section{RESULTS AND DISCUSSION}

Here we introduced an optimized method of DNA extraction to have sufficient amount of DNA with high quality required for molecular techniques such as cloning and PCR. Comparison between the amounts of extracted DNA from 4 different methods revealed that there are considerable differences in DNA yield between these extraction methods.

\section{DNA extraction from the soil}

For sample 3, yield of DNA extraction was the highest compare to other samples and between differenr methods by presented method was $130 \mathrm{ng} / \mu \mathrm{l}$ and was considerably higher than that of other methods which were $110 \mathrm{ng} / \mu \mathrm{l}$ for the method A, $90 \mathrm{ng} / \mu 1$ for the method B and $50 \mathrm{ng} / \mu 1$ for the method C. For other samples such pattern was also observed (Table 2). Extracted DNA is less sheared in method D comparing to the method A, but it cause more shearing in comparison with method B and C (figure 1).

Table 2 Comparison of DNA yield between different extraction methods and for three soil samples.

\begin{tabular}{|l|l|l|l|l|}
\hline \multicolumn{5}{|l|}{ Yield of DNA Extraction } \\
\hline $\begin{array}{l}\text { Soil } \\
\text { Sample }\end{array}$ & Method A & Method B & Method C & Method D \\
\hline $\mathbf{1}$ & 15 & 20 & 20 & 70 \\
\hline $\mathbf{2}$ & 80 & 65 & 40 & 100 \\
\hline $\mathbf{3}$ & 110 & 80 & 50 & 130 \\
\hline
\end{tabular}




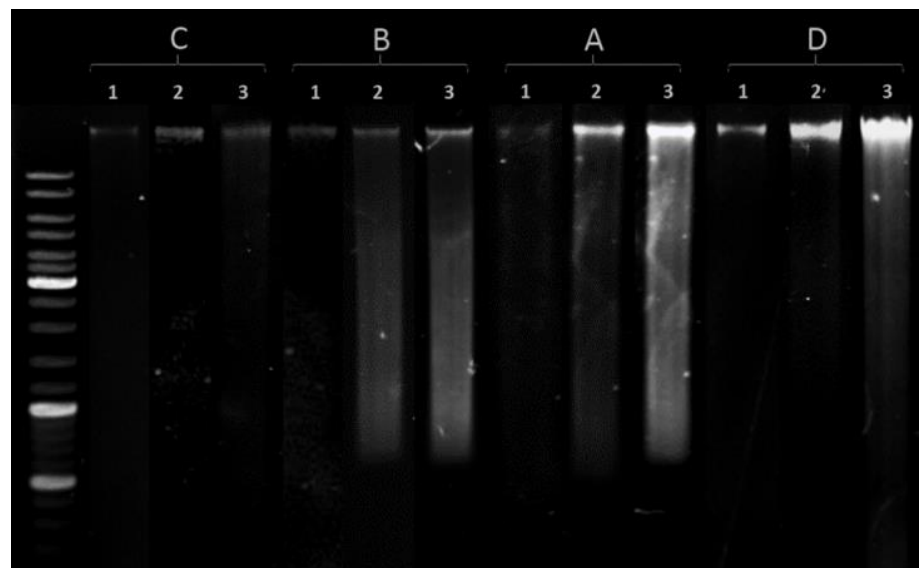

Figure 1 Agarose gel picture of DNA extracted from the soil with method C, B, A and D. C: Sonication lysis, B: Glass bead lysis, A: Liquid nitrogen based lysis as control methods and D: presented modified method.

Based on gel agarose analysis it was obvious that the highest DNA extraction yield is acquired with incursion step in liquid nitrogen. It seems that relatively harsh physical lysis steps in the extraction of DNA from the soil samples are crucial to obtain sufficient quantities of DNA. Liquid nitrogen step in method A and $\mathrm{D}$ was most effective lysis step through all four methods and bead beating was evidently more effective than sonication (figure 1). Bead beating was more efficient than lysis of cells with sonication and cycles of freeze-thaw. These results were relatively different from what obtained by Lakay and colleagues. They stated that bead beating method was more efficient in extracting DNA from incursion in liquid nitrogen and microwave based methods (Lakay et al. 2006) Zou $\boldsymbol{e t}$ al. (1996) showed 2 to 6 times higher yield of DNA extraction by grinding in liquid nitrogen comparing to the bead beating and $2 \%$ SDS plus freeze-thaw lysis methods, respectively. Pattern of DNA shearing is different between 4 methods. Sheared DNA in method $\mathrm{C}$ is much less than the other methods that evaluation of its DNA fragmentation pattern could be neglected. Various studies show that harsh physical modalities like grinding in liquid nitrogen causes considerable shearing of extracted DNA (Kabir $\boldsymbol{e t}$ al. 2003; Zhou et al. 1996) Introduced modified method minimizes the undesired damage to the DNA such as fragmentation. Comparison of method $\mathrm{A}$ and $\mathrm{D}$, indicates that although method D has additional two mechanical steps (figure 2), glass bead vortexing and freeze thaw cycles, it cause less DNA shearing than method A and the DNA fragments have larger sizes (figure 1). It is maybe due to the modification performed by the method D of DNA extraction. Addition of buffer before incursion in liquid nitrogen makes a solid iced structure that causes delimitation of this formation during the incursion by pestle. Also, application of freeze-thaw technique after mechanical and enzymatic steps can increase the releasing of genetic content of the lysed cells. Decreasing the time of incubation with SDS in $65^{\circ} \mathrm{C}$ was efficient on getting the less sheared DNA product (figure 1 and table $1)$.

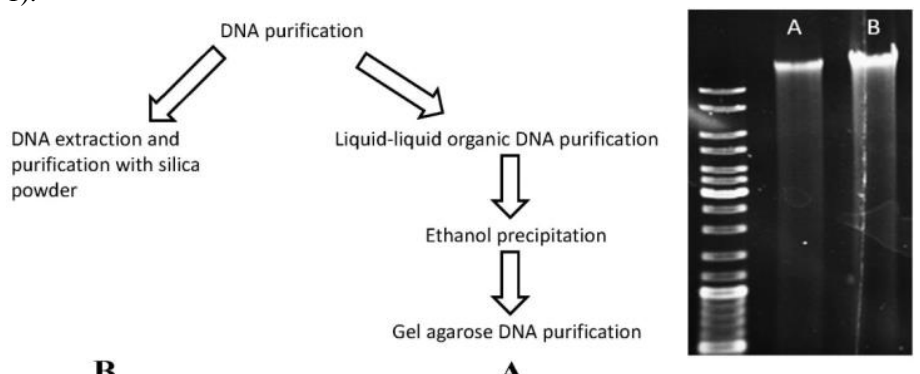

Figure 2 Comparison of two methods for purification of environmental DNA for sample 3. A: Purified DNA using conventional 3 step extraction and purification B: DNA purification by one step extraction and purification method.

\section{DNA liquid extraction and purification}

Yield and purity of extracted DNA were two important parameters to evaluate the DNA extraction and purification procedures (Zhou et al. 1996). One step extraction and purification of DNA which is introduced in this study was efficient in the term of quantity, purity and is cost effective (figure 2). The results obtained demonstrated that DNA extraction and purification with presented method was quicker and more efficient than conventional liquid-liquid organic extraction, ethanol precipitation and gel agarose purification. Purity of extracted DNA has not significant difference between new and conventional control method. For DNA extracted from soil sample 3, A280/A260 nm absorption ratio for conventional method was about 1.75 and that of our method was 1.73. Percentage of humic acid removal was $95.8 \%$ with humic acid content of $374 \mathrm{ng} / \mathrm{g}$ for crude DNA extracts and $16 \mathrm{ng} / \mathrm{g}$ for purified DNA using introduced method. For conventional purification method, humic acid removal was $97 \%$. Yield of DNA recovery for introduced purification method was $110 \mathrm{ng} / \mu \mathrm{l}(84 \%)$ and $95 \mathrm{ng} / \mu \mathrm{l}$ $(73 \%)$ for conventional method. DNA fragmentation shown by the gel agarose electrophoresis with one step extraction purification method was considerably lower comparing to the conventional methods and also, the fragmented DNA molecules in our improved method were larger in size (figure 2). Also, it was very rapid method comparing to the previous time consuming and hazardous methods that would reduce the quality of extracted DNA. In a similar study for DNA extraction protocol, Pushpender $\boldsymbol{e t}$ al. (2007) introduced a single step DNA extraction and purification procedure using Q-Sepharose which yielded 88\% reduction in humic acid content comparing to the $95 \%$ reduction by our introduced method of purification. Introduced method of DNA extraction and purification removes centrifugation steps that impose excess force on DNA and make it fragmented and sheared (Myers et al. 1973). This fact is notable in Figure 2 that DNA resulted from purification step in comparison of the new and conventional control methods, showed less amount of DNA shearing with new method.

\section{Ligation and transformation}

All samples extracted were successfully digested with restriction enzyme BamH1 and after ligation, transformed into the E. coli. Colony PCR result showed that colonies containing DNA fragments extracted by method D have larger inserts compared with those of other three methods. Average size of PCR bonds in obtained clones from method D and for sample 3 were $2.5-3 \mathrm{~kb}$. In three different control methods the average sizes were $1-2 \mathrm{~kb}$, almost negative and $1.5-2 \mathrm{~kb}$ in $\mathrm{A}, \mathrm{B}$ and $\mathrm{C}$, respectively (figure 3 ).

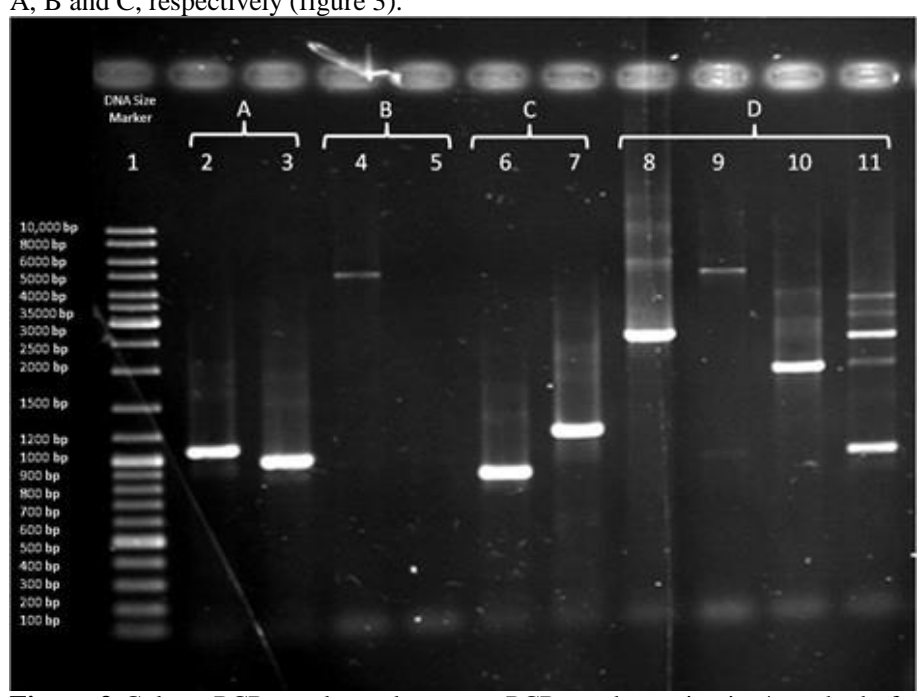

Figure 3 Colony PCR results and average PCR products size in 4 methods for sample 3. Line 1: DNA size marker, Line 2 and 3, colony PCR bands from liquid nitrogen incursion method (A). Line 4 and 5, colony PCR bands from glass bead based method (B), Line 6 and 7, colony PCR bands from sonication based method (C) Line 8-11, colony PCR bands from presented method (D).

\section{PCR}

PCR was successfully performed on DNA extracted from soil sample 3 with al four methods. Agarose gel result of PCR products showed that 16s rRNA and $18 \mathrm{~S}$ rRNA PCR results were almost the same between four DNA extraction protocols.

\section{CONCLUSION}

Most reliable approach for study of soil microbial community is molecular based method in which the first step should be the extraction of the DNA from the soil (Lakay et al, 2006). This process often has difficulties in term of application of lysis methods on the soil and also extracted DNA has humic acid contamination which inhibits many of reactions necessary for molecular studies (Trevors $\boldsymbol{e t}$ al, 1992). Here we introduced a modified liquid nitrogen based DNA extraction method and an innovative method were introduced that could make the extraction of DNA from environmental sources more easy and cheaper. This approach eliminates the need for using phenol for purification and in turn avoids the toxic and carcinogenic effects of this agent and also lessen the time needed for extraction and purification of environmental DNA.

\section{REFERENCES}

BÜRGMANN, H., PESARO, M., WIDMER, F. AND ZEYER, J. A. 2001. Strategy for optimizing quality and quantity of DNA extracted from soil. $J$ Microbiol Methods, 45, 7-20. http://dx.doi.org/10.1016/s0167-7012(01)00213-5 
CHEN, Z. X., LUO, R., HU, M., WU, J., WU, W. AND WEI, W. 2010. Impact of long-term fertilization on the composition of denitrifier communities based on nitrite 495496 reductase analysis in a paddy soil. Microb Ecol. 60, 850-861. http://dx.doi.org/10.1007/s00248-010-9700-z

DEGRANGE, V. AND BARDIN, R. 1995. Detection and counting of Nitrobacter populations in soil by PCR. J Appl Environ Microbio, 61, 2093-2098. FROSTEGARD, A., COURTOIS, S., RAMISSE, V., CLERC, S., BERNILLON, D., LE GALL, F., JEANNIN, P. AND NESME, X. 1999. Quantification of bias related to the extraction of DNA directly from soils. Appl Environ Microbiol, 65 5409-5420.

KRSEK, M. AND WELLINGTON, E. M. 1999. Comparison of different methods for the isolation and purification of total community DNA from soil. $J$ Microbiol Methods. 39, 1-16. http://dx.doi.org/10.1016/s0167-7012(99)00093-7 KUSKE, C. R., BANTON, K. L., ADORADA, D. L., STARK, P. C., HILL, K. K. AND JACKSON, P. J. 1998. Small-scale DNA sample preparation method for field PCR detection of microbial cells and spores in soil. Appl Environ Microbiol, 64, 2463- 2472

LAKAY, F. M., BOTHA, A. AND PRIOR, A. B. 2007. Comparative analysis of environmental DNA extraction and purification methods from different humic acid-rich soils. J Appl Microbiol, 102, 265-273. http://dx.doi.org/10.1111/j.13652672.2006.03052.x

LILES, M. R., MANSKE, B. F., BINTRIM, S. B., HANDELSMAN, J. AND GOODMAN, R. M. 2003. A census of rRNA genes and linked genomic sequences within a soil metagenomic library. Appl Environ Microbiol, 69, 2684 2691. http://dx.doi.org/10.1128/aem.69.5.2684-2691.2003

MARTIN-LAURENT, F., PHILIPPOT, L., HALLET, S., CHAUSSOD, R., GERMON, J. C., SOULAS, G. AND CATROUX, G. 2001. DNA Extraction from Soils: Old Bias for New Microbial Diversity Analysis Methods. Appl Environ Microbiol, 67, 2354-2359. http://dx.doi.org/10.1128/aem.67.5.23542359.2001

MICHALOWICZ, J. AND DUDA, W. 2007. Phenols - Sources and Toxicity. Pol J Environ Stud, 16, 347-362.

MILlER, D. N., BRYANT, J. E., MADSEN, E. L. AND GHIORSE, W. C. 1999. Evaluation and optimization of DNA extraction and purification procedures for soil and sediment samples. Appl Environ Microbiol, 65, 47154724.

MILLER, D. N. 2001. Evaluation of gel filtration resins for the removal of PCRinhibitory substances from soils and sediments. J Microb Methods, 44, 49-58. http://dx.doi.org/10.1016/s0167-7012(00)00228-1

MORE, M. I., HERRICK, J. B., SILVA, M. C., GHIORSE, W. C. AND MADSEN, E. L. 1994. Quantitative cell lysis of indigenous microorganisms and rapid extraction of microbial DNA from sediment. Appl Environ Microbiol, 60, 1572-1580.

MYERS, D. K., JOHNSON, L. D. AND GHETTY, K. G. 1973. Effect of relative centrifugal force on the apparent size of DNA from Escherichia coli cells. Can J Biochem, 51, 397-406. http://dx.doi.org/10.1139/o73-046

PREVOST-BOURE, N. C., CHRISTEN, R., DEQUITETS, S., MOUGEL, C., LELIEVRE, M., JULIET, C., SHAHBAZKIA, H. R., GUILlOU, L., ARROUAYS, D. AND RANJARD, L. 2011. Validation and application of a PCR primer set to quantify fungal communities in the soil environment by realtime quantitative PCR. PLoS One, 6, 22-46 http://dx.doi.org/10.1371/journal.pone.0024166

ROBE, P., NALIN, R., CAPELLANO, C., VOGEL, T. M. AND SIMONET, P. 2003. Extraction of DNA from soil. Eur $J$ Soil Biol, 39, 183-190. http://dx.doi.org/10.1016/s1164-5563(03)00033-5

SAMBROOK, J. AND DAVID, W., RUSSELL, D. 2001. Molecular cloning: a laboratory manual. 3rd ed. New York: CSHL

SETAYESH, N., SEPEHRIZADEH, Z. AND TABATABAI, Y. M. 2008 Molecular Cloning and Characterization of a cDNA Encoding L10 Ribosomal Protein from Mucor racemosus PTCC 5305. J Biol Sci, 8, 1193-1198. http://dx.doi.org/10.3923/jbs.2008.1193.1198

STACH, J. E. M., BATHE, S., CLAPP, J. P. AND BURNS, R. G. 2001. PCR SSCP comparison of $16 \mathrm{~S}$ rDNA sequence diversity in soil DNA obtained using different isolation and purification methods. FEMS Microbiol Ecol, 36, 139-151. http://dx.doi.org/10.1111/j.1574-6941.2001.tb00834.x

TEBBE, C. C. AND VAHJEN, W. 1993. Interference of humic acids and DNA extracted directly from soil in detection and transformation of recombinant DNA from bacteria and a yeast. Appl Environ Microbiol, 59, 2657-2665.

TREVORS, J. T., H, LEE, AND S. COOK. 1992. Direct extraction of DNA from soil. Microbiol Press Rel, 1, 111-115.

WANG, Y. AND TAKESHI, F. 2011. Evaluation of methods of determining humic acid in nucleic acid samples for molecular biology analysis. Biosci Biotechnol Biochem, 75, 355-357. http://dx.doi.org/10.1271/bbb.100597

YEATES, C., GILLINGS, M. R., DAVISON, A. D., ALTAVILLA, N. AND

VEAL, D. A. 1998. Methods for microbial DNA extraction from soil for PCR amplification. Biol proced online, 1, 40-47. http://dx.doi.org/10.1251/bpo6

YOUNG, C. C., BURGHOFF. R. L., KEIM. J. G., MINAK-BERBERO, V., LUTE, J. R. AND HINTON, S. M. 1993. Polyvinylpyrrolidone-agarose ge electrophoresis purification of polymerase chain reactionamplifiable DNA from soils. Appl Environ Microbiol, 59, 1972-1974.

ZHANG, Q., JUN, W. L. AND LONG, X. C. 2003. Streptomyces yunnanesis sp.nov., a mesophile from soils in Yunnan, China. Int J of System Ecol and Microbiol, 53, 217-221. http://dx.doi.org/10.1099/ijs.0.01851-0

ZHOU, J., BRUNS, M., AND TIEDJE, J. M. 1996. DNA recovery from soils of diverse composition. Appl Environ Microbiol, 7, 316-322. 